\title{
Results From Bulgaria's 2018 Report Card on Physical Activity for Children and Youth
}

\author{
Bilyana Mileva
}

\section{Introduction}

In Bulgaria, the period of transition (1989-1998) from Communism to Democracy, and the two decades that followed, witnessed broad social and economic changes. The transition to a market-based economy was accompanied by less regular Physical Activity and Organized Sport, viewed as unaffordable luxuries by large segments of the population whose standards of living were going down. Recent data from the World Health Organization quoting unpublished national research show that Bulgarian youth are among the lowest physically active in Europe. ${ }^{1}$ However, there is limited data to accurately estimate the extent of this problem. The 2018 Report Card is a summary of the best available data on physical activity among Bulgarian children and youth.

\section{Methods}

Bulgaria's 2018 Report Card (Figure 1) summarizes the limited data, available on the physical activity levels of Bulgarian children and youth such as Eurostat 914 Barometer survey or UNICEF Health Behavior in School-aged Children and other national sources. However, facing this insufficiency, disparity and incomparability of existing data, the core of Bulgaria's 2018 Report Card was informed by a survey of 1014 Bulgarian children aged 6 to 18 years and their parents. The survey was designed to capture data about the Physical Activity Indicators that are common to the Global Matrix 3.0. The survey was conducted between September 15 and 26, 2016 as part of the ActiveVoice project, with the support of Erasmus+ programme of the EU. The Report Card Grades for the indicators were assigned using benchmarks provided by the Active Healthy Kids Global Alliance. ${ }^{2}$ Data obtained from the dedicated survey, were complimented with the analysis of policy documents issued by the Bulgarian government agencies, municipalities and NonGovernmental Organization (NGOs), as well expert analyses and evaluations.

\section{Results and Discussion}

Table 1 presents results from Bulgaria's 2018 Report Card. The results were presented following a template provided by the Active Healthy Kids Global Alliance (www.activehealthykids.org). Attention was focused on appropriate highlights of the most important data, and to put them into a format that could be easily accessed by public media, government agencies and municipalities,

Mileva is with the BG be Active Association, Plovdiv, Bulgaria. Mileva (bilyana@ bgbeactive.org) is corresponding author.
NGOs, researchers and other practitioners in the field. As a post-communist country ${ }^{3}$ with high regard for competitive sport, we see high levels of children's participation in Organized Sport (grade $\mathrm{C}+$ ) in Bulgaria. The proportion of children that meet the Lifelong Involvement in Sport and Physical Activity (LISPA) Group's recommendations of two or more times of Organized Sport per week is $70 \%$ (in and out of school).

Contrary to the higher proportions of children participating in Organized Sport, only $30 \%$ of the Bulgarian children (6-18) meet the recommended daily minimum of 60 minutes of moderate-tovigorous intensity physical activity, while $70 \%$ of the students spend more than 2 hours in front of a recreational screen. Specific groups (overweight or obese students, children from ethnic minorities or with financial difficulties) demonstrate higher levels of inactivity and sedentary behavior. ${ }^{4,5}$ These groups are especially vulnerable (also in combination with other risk behaviour as unhealthy diet, tobacco use, etc.) to the associated health and economic consequences, particularly in adulthood. In that situation, the NGOs have special role and responsibility to be the actors of change and to bring the citizens closer to the decision makers.

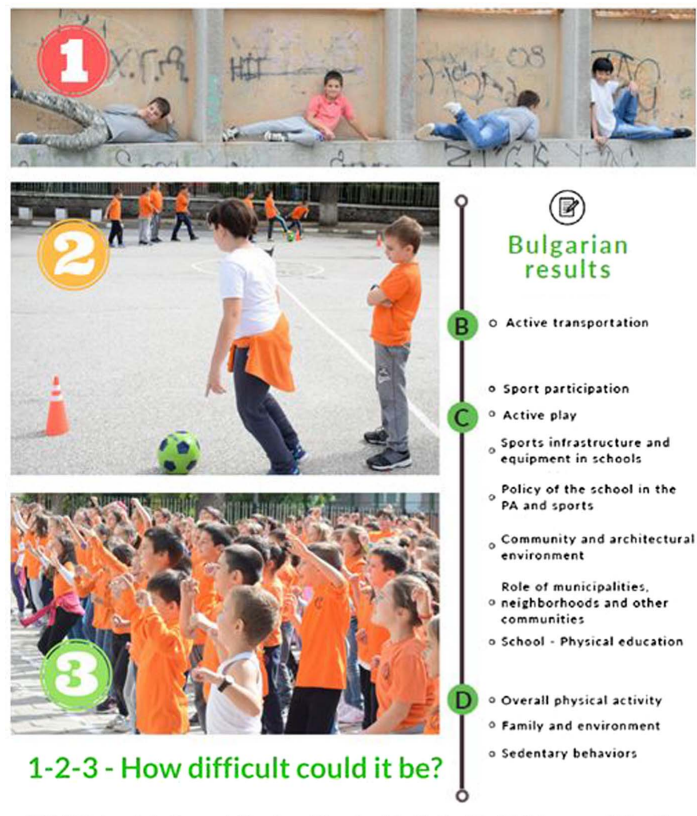

2018 Bulgaria's Report Card on Physical Activity for Children and Youth is alarming - Bulgarian children are not active enough!

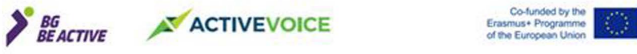

Figure 1 - Bulgaria's 2018 Report Card cover. 
Table 1 Grades and rationales for Bulgaria's 2018 Report Card

\begin{tabular}{|c|c|c|}
\hline Indicator & Grade & Rationale \\
\hline $\begin{array}{l}\text { Overall Physical } \\
\text { Activity }\end{array}$ & $\mathrm{D}+$ & $\begin{array}{l}\text { Approximately one third (30\%) of children and youth aged } 6 \text { to } 18 \text { years, meet the recommended daily minimum of } \\
60 \text { minutes of physical activity. If the } 5 \text { percent declaring engaging in such activity for at least six days a week is } \\
\text { added, the total proportion of children and youth meeting the guidelines will be approaching } 35 \% \text {. }\end{array}$ \\
\hline $\begin{array}{l}\text { Organized Sport } \\
\text { Participation }\end{array}$ & $\mathrm{C}+$ & $\begin{array}{l}60 \% \text { of children and youth participate in Organized Sports at school while } 56 \% \text { engage in Organized Sports out of } \\
\text { school. The proportion of children and youth engaging in Organized Sport at least } 3 \text { or more times per week is almost } \\
\text { similar in and out of school ( } 27 \% \text { and } 29 \% \text { respectively). The proportion of Bulgarian children and youth meeting the } \\
\text { LISPA Group recommendations is } 70 \% \text {. }\end{array}$ \\
\hline Active Play & $\mathrm{C}+$ & $\begin{array}{l}55 \% \text { of children aged } 6-18 \text { year have outdoor activities for } 3 \text { or more days weekly, and the proportion is higher }(63 \%) \\
\text { when considering only those aged between } 6 \text { and } 15 \text { years. }\end{array}$ \\
\hline Active Transportation & $\mathrm{B}-$ & $\begin{array}{l}53 \% \text { of children and youth reported walking, biking, or skating, etc. to go to school and back. The Bulgarian Active } \\
\text { Kids Survey considered two aspects (means of transportation and time it took to school) of the active transportation } \\
\text { of children and youth. Since we found that for approximately } 16 \% \text {, it takes less than } 5 \text { minutes to get to school, when } \\
\text { evaluating the active transportation we took a conservative approach and excluded this group. If this group is } \\
\text { included in evaluation, then the proportion increases to } 64 \% \text {. The Grade B was awarded because the research does } \\
\text { not take into account other locations that can reach using active transportation. }\end{array}$ \\
\hline Sedentary Behaviours & $\mathrm{D}$ & $\begin{array}{l}\text { Approximately } 70 \% \text { of children and young people in Bulgaria spend two or more hours sitting in front of a } \\
\text { recreational screen, tablet, and } 75 \% \text { reported spending two hours or more in other sedentary activities. Only } 16 \% \text { of } \\
\text { children spend less than one hour in front of a recreational screen, while } 15 \% \text { spend more than } 6 \text { hours seated. } \\
\text { Another } 40 \% \text { of children spend over five hours a day in the two types of sedentary behaviour. }\end{array}$ \\
\hline Physical Fitness & INC & There was not sufficient data to grade this indicator \\
\hline Family and Peers & $\mathrm{D}$ & $\begin{array}{l}\text { Approximately } 25 \% \text { of Bulgarian families practice sports for two or more times a week. One third of the families, } \\
\text { report that they sports facilities and/ or other sports equipment at home. Almost one third of families, finances the } \\
\text { sporting activities for their children, while about } 1 / 3 \text { of families, reported that they never exercise. Only } 9 \% \text { of } \\
\text { children indicate that all their friends are practicing some sport, while another one third declare this for about half of } \\
\text { friends. The proportion of students whose friends engage in sports for two or more times a week was } 43 \% \text {. }\end{array}$ \\
\hline School & $\mathrm{C}$ & $\begin{array}{l}\text { This indicator was graded based on the children and their parents' assessment of the quality of teachers and classes on } \\
\text { physical education and sport, formal requirements, content of curricula, duration of hours. In addition, expert opinion } \\
\text { was also used. 50\% of parents and children firmly assess their school's sport hall and facilities as very good. 55\% } \\
\text { declare that the sport hall facilities were renovated during the last two years. Based on this overall positive } \\
\text { assessment of sporting equipment and outdoor facilities that encourage physical activities at the schools, as well as } \\
\text { expert opinion, the indicator was assigned a grade C. }\end{array}$ \\
\hline $\begin{array}{l}\text { Community and } \\
\text { Environment }\end{array}$ & $\mathrm{C}$ & $\begin{array}{l}\text { A conservative approach was used. Although about } 65 \% \text { of children and youth declare that they have easy access to } \\
\text { the nearest playgrounds and } 63 \% \text {, to parks with sports facilities. The assessments of the other elements of a } \\
\text { supportive community environment are significantly lower: } 41 \% \text { for bicycle paths, } 33 \% \text { for running grounds, and } \\
30 \% \text { for swimming pools. The overall positive assessment of the state of these facilities is } 45 \% \text {, and of the various } \\
\text { aspects of their safety is between } 50 \text { and } 60 \% \text {. }\end{array}$ \\
\hline Government & INC & $\begin{array}{l}\text { Invitations and questioners were sent to different government official in local (municipal), regional, and at the } \\
\text { national level (Ministry of Youth and Sport) but no official answers were returned. Because of our failure to obtain } \\
\text { information, this indicator was assigned an incomplete grade. }\end{array}$ \\
\hline
\end{tabular}

\section{Conclusion}

The high levels of inactivity and sedentary behaviour are a natural consequence of the gaps in governmental and local policies and insufficient funding. There is a strong need for political will, to tackle the problem. However, inactivity levels can be associated with cultural specifics of Bulgarians and there is an urgent need of updated programmes for Physical Education targeting especially the hard-to-reach children and adolescents.

\section{Acknowledgement}

The author thanks Dr. Ivan Tchalakov, full professor, and Dr. Donka Kiskinova, assistant professor from the Department of Applied and Institutional Sociology, University of Plovdiv, Bulgaria, for their support for the development of the Bulgarian Report Card.

\section{References}

1. WHO Physical Activity Factsheet Bulgaria. Physical Activity in Children and Adolescents. Unpublished research. 2010. http://
www.euro.who.int/_data/assets/pdf_file/0010/288091/BULGARIAPhysical-Activity-Factsheet.pdf?ua=1

2. Colley RC, Brownrigg M, Tremblay MS. A model of knowledge translation in health. The Active Healthy Kids Canada Report Card on physical activity for children and youth. Health Promotion Practice. 2012;13(3):114-115. doi:10.1177/1524839911432929

3. Edelman R, Hilbrenner A, Brownell S. Sport Under Communism. In: Smith SA, ed. The Oxford Handbook of the History of Communism. Oxford University Press; 2014 January 1. http://www. oxfordhandbooks.com/view/10.1093/oxfordhb/9780199602056.001. 0001/oxfordhb-9780199602056-e-011.

4. De la Haye K, Robins G, Mohr P, Wilson C. Obesity-related behaviors in adolescent friendship networks. Soc Networks. 2010;32(3):161-167. http://www.academia.edu/14236344/Obesityrelated_behaviors_in_adolescent_friendship_networks

5. Carrell SE, Hoekstra M, West JE. Is poor fitness contagious?: Evidence from randomly assigned friends. $J$ Public Econ. 2011;95(7-8):657-663. https://econpapers.repec.org/article/eeepubeco/ v_3a95_3ay_3a2011_3ai_3a7-8_3ap_3a657-663.htm. 